\title{
PENGETAHUAN MASYARAKAT KEPULAUAN SANGIHE TENTANG CORONA VIRUS DISEASE 2019
}

\section{KNOWLEDGE OF SANGIHE PEOPLE ABOUT CORONA VIRUS DISEASE 2019}

\author{
Melanthon Junaedi Umboh, Maryati Agustina Tatangindatu \\ Jurusan Kesehatan, Program Studi Keperawatan, Politeknik Negeri Nusa Utara \\ Email: melanthon.umboh@gmail.com
}

\begin{abstract}
Abstrak: Covid-19 merupakan penyakit yang disebabkan oleh virus corona. Data resmi dari Pusat Penanggulangan Covid-19 Republik Indonesia menyebutkan bahwa jumlah kasus covid-19 terus mengalami pengingkatan. Pengetahuan tentang Covid-19 merupakan hal yang penting harus ada pada seorang individu sebab beberapa penelitian menemukan pengetahuan yang baik akan mengurangi angka kejadian terjangkit atau penularan Covid-19. Tujuan dari penelitian ini yaitu mengetahui gambaran pengetahuan Masyarakat tentang Covid-19 dan Pencegahannya di Kampung Naha 1 Kecamatan Tabukan Utara, Kabupaten Kepulauan Sangihe.Penelitian ini merupakan jenis penelitian kuantitatif dengan metode deskriptif yang dilaksanakan Kampung Naha 1 Kecamatan Tabukan Utara, Kabupaten Kepulauan Sangihe pada bulan Juli-Desember 2020. Pengambilan sampel secara purposivesampling.Variabel pada penelitian ini yaitu pengetahuan masyarakat tentang covid19.Pengumpulan data menggunakan kuesioner dan analisis data univariat menggunakan IBM SPSS Statistics 25. Hasil penelitian menunjukkan sebagian besar responden berjenis kelamin laki-laki (71.9\%), termasuk pada kategori usia produktif yaitu 25-54 tahun (71.9\%) serta memiliki pendidikan terakhir SD (36\%). Hasil analisis menunjukkan bahwa masyarakat Kampung Naha 1 telah memiliki pengetahuan yang baik tentang penyebab covid-19 dengan persentase $98 \%$ begitu pula dengan pengetahuan tentang upaya pencegahan covid-19 dengan persentase 96.9\%. Masyarakat Kampung Naha 1 Kecamatan Tabukan Utara memiliki pengetahuan yang baik dimana sebagian besar responden dapat menjawab pertanyaan tentang penyebab, gejala dan pencegahan penularan covid-19 dengan benar.
\end{abstract}

Kata Kunci: Covid-19, Pengetahuan, Pencegahan

\begin{abstract}
Covid-19 is a disease caused by the corona virus. Official data from Pusat Penanggulangan Covid-19 Republik Indonesia states that the number of Covid-19 cases continued to increase. Knowledge about Covid-19 was important thing that must be in an individual because several studies have found that good knowledge will reduce the incidence of contracting or transmitting Covid-19. The purpose of those study to describe of community knowledge about the causes and prevetion of Covid-19 in Naha 1, Tabukan Utara, Sangihe. Those research through a quantitative research with descriptive method was carried out in Naha 1, Tabukan Utara, Sangihe in July to December 2020. Sampling method used to purposive sampling. The variable in this study was people knowledge about Covid-19. Data collection used questionnaires and univariate data to analyis used IBM SPSS Statistics 25. The results showed that most of the respondents were male (71.9\%), included in the productive age category, namely 25-54 years (71.9\%) and had the latest elementary education (36\%). The results of the analysis show that the people of Kampung Naha 1 have a good knowledge of the causes of Covid-19 with a percentage of $98 \%$ as well as knowledge of efforts to prevent Covid-19 with a percentage of $96.9 \%$. The people of Kampung Naha 1, North Tabukan District have good knowledge about the causes, symptoms and prevention of covid-19 transmission. Those because the most respondents were correctly answering questions about the causes, symptoms and prevention of Covid19 transmission.
\end{abstract}

Keyword: Covid-19, Knowledge, Prevention 


\section{PENDAHULUAN}

Penyakit Covid-19 adalah penyakit menular yang disebabkan oleh virus Severe Acute Respiratory Syndrome Coronavirus-2 (SARS-CoV2). WHO telah menetapkan Covid-19 sebagai pandemi secara global tanggal 11 Maret 2020, dimana terdapat lebih dari 118.000 kasus di 114 negara dan 4.291 orang telah meninggal dunia. Data resmi hari pada April 2020 menyebutkan jumlah kasus positif covid-19 sebanyak 2.956 orang, dinyatakan sembuh setelah perawatan di rumah sakit 220 kasus,dan yang meninggal dunia 240 orang,angka ini dengan cepat bertambah dikarenakan penularan oleh orang tanpa gejala (BNPB, 2020).

Akhir-akhir ini penularan terjadi dari manusia ke manusia lainnya salahsatunya disebabkan oleh riwayat orang bepergian antar daerah maupun antar negara. Jalan-jalan keluar negeri, keluar daerah dan luar kota sudah menjadi tren dikalangan banyak orang di masyarakat saat ini dan dianggap sebagai gaya hidup termasuk masyarakat yang ada di Kabupaten Kepulauan Sangihe bahkan disaat status Pandemipun masih melakukan aktivitas ini disementara himbauan pemerintah tidak diperkenankan mengadakan perjalanan dari dan ke luar negeri atau daerah yang terdapat banyak kasus positif untuk mencegah terjadinya penularan.

Berdasarkan berbagai macam penelitian ilmiah, Covid-19 proses penularannya melalui kontak erat berupa droplet, kecuali jika ada tindakan medis yang memiliki terjadinya aerosol (seperti bronkoskopi, nebulisasi dan lain sebagainya) dimana dapat memicu terjadinya resiko penularan melalui aerbone (Perdatin, 2020).

Salah satu upaya atau cara terbaik mencegah dan memperlambat penularan atau penyebaran virus tersebut adalah dengan memberikan edukasi tentang covid-19,kebiasaan perilaku hidup sehat dan memberlakukan kebiasaan membersihkan tangan dengan cara mencuci dengan baik dan benar. Pengetahuan tentang Covid-19 merupakan hal yang penting harus ada pada seorang individu sebab beberapa penelitian menemukan pengetahuan yang baik akan mengurangi angka kejadian terjangkit atau penularan Covid-19.

Kampung Naha I adalah salah satu kampung di kecamatan Tabukan Utara. Data Demografi memiliki 3 Lindongan / Lingkungan, Jumlah penduduk 799 jiwa, Kepala Keluarga 255, daerah ini sangat strategis dari segi sarana transportasi udara karena memiliki pelabuhan / bandara udara satu - satunya yang dimiliki Kabupaten Kepulauan Sangihe. Berdasarkan fenomena yang telah dipaparkan maka penulis perlu melakukan penelitian terkait Gambaran PengetahuanMasyarakat Tentang Covid-19 dan Pencegahannya di Kampung Naha Kecamatan Tabukan Utara.Penelitian ini betujuan untuk mengetahui gambaran pengetahuan masyarakat tentang covid-19 dan pencegahannya di Kampung Naha 1 Kecamatan Tabukan Utara.

\section{METODE PENELITIAN}

Penelitian ini merupakan jenis penelitian kuantitatif dengan metode deskriptif untuk mengetahui gambaran pengetahuan pada masyarakat di Kampung Naha Kecamatan Tabukan Utara. Penelitian ini dilaksanakan pada bulan Juli-Desember 2020 di Kampung Naha Kecamatan Tabukan Utara. Pengambilan sampel pada penelitian ini berdasarkan non-probability sampling dengan menggunakan purposive sampling. Jumlah sampel pada penelitian ini yakni 128 responden. Variabel pada penelitian ini yaitu pengetahuan masyarakat tentang Covid-19. Pengumpulan data menggunakan kuesioner dan analisis data univariat menggunakan IBM SPSS Statistics 25 .

\section{HASIL DAN PEMBAHASAN}

Berdasarkan tabel 1 dapat dilihat bahwa pada penelitian ini, sebagian besar responden berjenis kelamin laki-laki yaitu $92 \quad(71,9 \%)$ responden. Berdasarkan kelompok umur, maka responden terbanyak masuk pada kategori umur 25-54 tahun 
dengan jumlah $92(71,9 \%)$ responden. Apabila dilihat berdasarkan karakteristik pendidikan, responden terbanyak memiliki pendidikan terakhir Sekolah Dasar (SD) dengan jumlah $47 \quad(36,7 \%)$ Responden. Berdasarkan pekerjaan maka responden terbanyak memiliki pekerjaan sebagai petani dengan jumlah 44 $(34,4 \%)$.

Tabel 1. Distribusi Responden Berdasarkan Karakteristik

\begin{tabular}{lll}
\hline Karakteristik Responden & $\mathrm{n}$ & $\%$ \\
\hline Jenis Kelamin & 92 & 71.9 \\
Laki-laki & 36 & 28.1 \\
Perempuan & & \\
\hline Kelompok Umur (Tahun) & 0 & 0 \\
$<14$ & 2 & 1.6 \\
$15-24$ & 92 & 71.9 \\
$25-54$ & 34 & 26.6 \\
\hline 55 & & \\
Pendidikan Terakhir & 47 & 36.7 \\
SD & 22 & 17.2 \\
SMP & 46 & 35.9 \\
SMA & 13 & 10.2 \\
Pendidikan Tinggi & & \\
Pekerjaan & 3 & 2.3 \\
Pegawai Negeri Sipil (PNS) & 8 & 6.3 \\
Honorer & 10 & 7.8 \\
Wiraswasta & 44 & 34.4 \\
Petani & 6 & 4.7 \\
Nelayan & 12 & 9.4 \\
Buruh & 23 & 18 \\
IRT & 9 & 7 \\
Supir & 13 & 10.2 \\
Lainnya & & \\
\hline & & \\
& &
\end{tabular}

Berdasarkan tabel 2 dapat dilihat bahwa sebagian besar responden termasuk pada kategori berpengetahuan baik tentang etiologi dan gejala covid 19 yaitu $126(98,4 \%)$ responden sedangkan $2(1,6 \%)$ responden termasuk pada kategori berpengetahuan cukup. Dilihat berdasarkan pengetahuan tentang pencegahan penularan covid-19, sebanyak 124 (96,9\%) responden termasuk pada kategori berpengetahuan baik sedangkan $4(3,1 \%)$ responden termasuk pada kategori berpengetahuan cukup.
Tabel 2. Distribusi Responden Berdasarkan Pengetahuan Tentang Covid-19

\begin{tabular}{lcc}
\hline \multicolumn{1}{c}{ Pengetahuan } & $\mathrm{n}$ & $\%$ \\
\hline Pengetahuan tentangpenyebab dan gejala Covid-19 & & \\
Baik & 126 & 98.4 \\
Cukup & 2 & 1.6 \\
Kurang & 0 & 0 \\
\hline Pengetahuan tentangpencegahan penularan Covid-19 & & \\
Baik & 124 & 96.9 \\
Cukup & 4 & 3.1 \\
Kurang & 0 & 0 \\
\hline
\end{tabular}

Tabel 2 menunjukkan masyarakat kampung Naha dikategorikan memiliki pengetahuan yang baik terkait penyebab dan gejala serta pencegahan penularan covid-19. Hal ini ditunjukkan dengan mayoritas jawaban benar pada item-item pernyataan yang diberikan. Hasil penelitian ini sejalan dengan penelitian yang dilakukan oleh Yanti (2020) yang menunjukkan bahwa masyarakat Desa Sumerta Kelod dikategorikan memiliki pengetahuan yang baik terkait pandemi COVID-19.Penelitian serupa juga dilakukan oleh Prihati (2020) yang menunjukkan bahwa masyarakat Kelurahan Baru Kotawarngin Barat memiliki pengetahuan yang baik tentang covid-19.Penelitian tersebut juga menunjukkan bahwa semakin baik pengetahuan masyarakat, maka semakin baik pula tindakan masyarakat dalam pencegahan covid-19. Menurut Notoatmodjo (2011), pengetahuan atau kognitif merupakan domain yang sangat penting untuk terbentuknya tindakan seseorang (overt behavior). Selain itu, perilaku yang didasarkan oleh pengetahuan akan lebih langgeng daripada perilaku yang tidak didasari oleh pengetahuan.

Pengetahuan masyarakat tentang penyebab dan gejala covid-19 dlihat berdasarkan 6 item pernyataan. Diantara item-item tersebut, terdapat 1 item pernyataan dengan frekuensi jawaban salah paling banyak yaitu pernyataan yang menyebutkan bahwa Covid-19 merupakan penyakit yang disebabkan oleh corona virus jenis baru. Dari pernyataan tersebut, $17.2 \%$ responden menjawab salah. Faktanya menurut Kemenkes (2020), 
Coronavirus Disease 2019 (COVID-19) adalah penyakit menular yang disebabkan oleh Severe Acute Respiratory Syndrome Coronavirus 2 (SARS-CoV-2). SARS-CoV-2 merupakan coronavirus jenis baru yang belum pernah diidentifikasi sebelumnya pada manusia. Ada setidaknya dua jenis corona virus yang diketahui menyebabkan penyakit yang dapat menimbulkan gejala berat seperti Middle East Respiratory Syndrome (MERS) dan Severe Acute Respiratory Syndrome (SARS).

Pengetahuan masyarakat tentang pencegahan penularan covid-19 dilihat berdasarkan 14 item pernyataan. Diantara item-item tersebut, terdapat 4 item pernyataan dengan frekuensi jawaban salah paling banyak. Pernyataan pertama dengan frekuensi jawaban salah paling banyak yaitu penyataan bahwa menyemprot seluruh anggota badan dengan cairan desinfektan adalah cara terbaik mencegah covid-19 dengan jumlah responden yang menjawab salah yaitu 28.1\%. Menurut Kemenkes (2020c), desinfeksi merupakan proses menghilangkan sebagian besar atau semua mikroorganisme pathogen kecuali spora bakteri yang di permukaan benda bon-biologis. Menyemprotkan desinfektan ke tubuh dapat berbahaya untuk membrane mukosa sehingga berpotensi menimbulkan risiko terhadap kesehatan. Pajanan desinfektan langsung ke tubuh secara terus menerus dapat menyebabkan iritasi kulit dan iritasi pada saluran pernapasan. Berdasarkan hal tersebut maka tidak dianjurkan penggunaan bilik desinfesi di tempat dan fasilitas umum serta pemukiman.

Pernyataan kedua dengan frekuensi salah paling banyak yaitu pernyataan bahwa penggunaan masker menutup hidung dan mulut sebaiknya 4 jam dengan jumlah responden yang menjawab salah yaitu $16 \%$. Faktanya dalam surat edaran dari kementerian kesehatan, penggunaan masker kain maksimal 4 jam dan harus dicuci menggunakan deterjen (Kemenkes, 2020b). Pernyataan ketiga dengan frekuensi salah paling banyak yaitu pernyataan bahwa masker $\mathrm{N}-25$, masker medis, sarung tangan medis sebaiknya digunakan paramedis, masyarakat cukup gunakan masker dari bahan kain dengan jumlah responden yang menjawab salah yaitu 60.9\%. Menurut WHO (2020) dalam anjuran mengenai penggunaan masker dalam konteks covid-19, masker medis di prioritaskan bagi tenaga kesehatan. Hal ini disebabkan karena penggunaan masker medis oleh masyarakat dapat menciptakan rasa aman yang semu sehingga langkahlangkah kesehatan lain seperti menjaga kebersihan tangan dan menjaga jarak fisik tidak dihiraukan dan tetap menyentuh bagian wajah di balik masker dan di bawah mata. Hal tersebut menyebabkan kerugian serta mengakibatkan masker tidak dapat digunakan oleh orang-orang yang terlibat dalam pelayanan kesehatan yang paling membutuhkan masker, terutama saat ketersediaan masker terbatas.

Pernyataan keempat dengan frekuensi salah paling banyak yaitu pernyataan bahwa melawan serta mencegah covid-19 hanyalah tugas pemerintah dan tenaga medis dengan jumlah responden yang menjawab salah yaitu 16\%. Faktanya dalam buku pedoman pencegahan dan pengendalian coronavirus disesase (covid-19) oleh Kemeterian Kesehatan, masyarakat memiliki peran penting dalam memutus mata rantai penularan COVID-19 agar tidak menimbulkan sumber penularan baru. Mengingat cara penularannya berdasarkan droplet infection dari individu ke individu, maka penularan dapat terjadi baik di rumah, perjalanan, tempat kerja, tempat ibadah, tempat wisata maupun tempat lain dimana terdapat orang berinteaksi sosial. Oleh sebab itu upaya pencegahan covid-19 perlu dilakukan oleh semua pihak termasuk masyarakat.

Menurut Notoatmodjo (2011), pemberian informasi tentang cara hidup sehat erta cara mencegah penyakit dan sebagainya akan meningkatkan pengetahuan masyarakat tentang hal tersebut. Selanjutnya dengan pengetahuan itu akanmenimbulkan kesadaran mereka dan akhirnya akan menyebabkan orang berperilaku sesuai dengan pengetahuan yang dimilikinya. Penelitian yang dilakukan oleh $\mathrm{R}$ dan 
Alimansur (2020) menunjukkan bahwa adanya hubungan pengetahuan upaya pencegahan terhadap kepatuhan pencegahan penularan Covid Kota Kediri dengan $P$ value $<0.05$. Penelitian lain yang dilakukan oleh Wiranti at al (2020), menunjukkan bahwa responden yang patuh terhadap kebijakan Pembatasan Sosial Berskala Besar (PSBB) lebih banyak dilakukan oleh responden dengan pengetahuan kebijakan PSBB yang baik. Kepatuhan masyarakat akan protokol pencegahan covid-19 tentunya akan berpengaruh pada penurunan angka kejadian covid-19.

\section{KESIMPULAN}

Berdasarkan penelitian ini dapat disimpulkan bahwa sebagian besar responden di Kampung Naha memiliki pengetahuan yang baik terkait penyebab dan gejala Covid-19 yakni 98,4\% serta 96,9\% responden memiliki pengetahuan baik terkait pencegahan penularan Covid-19. Pengetahuan masyarakat yang dikategorikan baik tersebut dikarenakan sebagian besar responden dapat menjawab pertanyaan tentang penyebab, gejala dan pencegahan penularan Covid-19 dengan benar. Upaya promosi kesehatan untuk meningkatkan pengetahuan masyarakat terkait upaya pencegahan Covid-19 tetap perlu dilakukan mengingat masih ada beberapa item pernyataan yang tidak dapat dijawab dengan benar oleh responden.

\section{DAFTAR RUJUKAN}

BNPB RI. (2020). Situasi Covid-19 Indonesia. Available at: https://bnpbinacovid19.hub.arcgis.com/ (Accessed: 10 Agustus 2020)

Kemenkes RI. (2020a). Pedoman Pencegahan dan Pegendalan Corona Virus Disease (Covid-19). Jakarta: Kementerian Kesehatan RI

Kemenkes RI. (2020b). Surat Edaran Kementerian Kesehatan Nomor HK.02.02/I/385/2020 Tentang Penggunaan Masker dan Penyediaan Sarana Cuci
Tangan Pakai Sabun (CTPS) Untuk Mencegah Penularan Covid-19.

Kemenkes RI. (2020c). Surat Edaran Kementerian Kesehatan Nomor HK.02.02/III/375/2020 Tentang Penggunaan Bilik Desinfeksi Dalam Rangka Pencegahan Penularan Covid-19.

Notoatmodjo, S. (2011). Kesehatan Masyarakat Ilmu dan Seni. Jakarta: Rineka Cipta. Perdatin. (2020). Buku Pedoman Penanganan Pasien Kritis Covid19. Makassar: Perdatin

Prihati, D. R., Wirawati, M. K., \& Endang Spriyanti. (2020). Analisis Pengetahuan Dan Perilaku Masyarakat Di Kelurahan Baru Kotawaringin Barat Tentang Covid 19. Malahayati Nursing Journal, 2(September), 780-790.

R, Elfi Quyumi \& Moh Alimansur. (2020). Upaya Pencegahan Dengan Kepatuhan Dalam Pencegahan Penularan Covid-19 Pada Relawan Covid. JPH RECODE 4(1): 81-87.

WHO. (2020). Panduan Penanganan Penyebaran Covid-19 di Indonesia. Jakarta: Kementerian Kesehatan RI.

WHO. (2020). Anjuran Mengenai Penggunaan Masker Dalam Konteks Covid-19, (April).

Wiranti, Ayun Sriatmi \& Wulan Kusumastuti. (2020). Determinan Kepatuhan Masyarakat Kota Depok Terhadap Kebijakan Pembatasan Sosial Berskala Besar Dalam Pencegahan Covid-19.JKKI 9(3): 117-24.

Yanti, N. P. E. D., Nugraha, I. M. A. D. P., Wisnawa, G. A., Agustina, N. P. D., \& Diantari, N. P. A. (2020). Gambaran Pengetahuan Masyarakat Tentang Covid-19 dan Perilaku Masyarakat di Masa Pandemi Covid-19. Jurnal Keperawatan Jiwa, $8(3)$, 491-50. 
74 Jurnal Ilmiah Sesebanua, Volume 4, Nomor 2, November 2020, hlm. 69-73 